\title{
Immunological and Cytopathological Assessment of Trichomonas vaginalis Infection in Asymptomatic and Symptomatic Females at Menoufia Governorate, Egypt
}

\author{
Asmaa R. Hegazy ${ }^{1}$, Wafaa M. El Kersh ${ }^{1}$, Ismail M. Moharm¹, \\ Amany I. Ammar ${ }^{1 *}$, Aiat S. Hemida ${ }^{2}$ and Amany F. Atia ${ }^{1}$ \\ ${ }^{1}$ Medical Parasitology, Faculty of Medicine, Menoufia University, Egypt \\ ${ }^{2}$ Pathology department, Faculty of Medicine, MenoufiaUniversity, Egypt \\ *Corresponding author
}

\section{A B S T R A C T}

\section{Keywords}

Trichomonas vaginalis,

Menoufia,

Cytokines, IL-22,

IL-17, IL-2, IFN- $\gamma$,

Cytopathological

changes

\section{Article Info}

Accepted:

xx March 2020

Available Online:

xx April 2020
Trichomonas vaginalis (T. vaginalis) is a common health problem all over the world. The present study aimed to determine the prevalence rate and risk factors of $T$. vaginalis in females in Menoufia Governorate, Egypt and assess some immunological parameters includingIL-2, IL-17, IL22 and INF and their relation to cytopathological changes in asymptomatic and symptomatic $T$. vaginalis infected females. Two hundred females aging between 18 and 50 years' old were classified into two groups: Group I: Asymptomatic females subdivided into subgroup I a (non-infected) from which control subgroup were selected and I b (infected).Group II: Symptomatic females was subdivided into subgroup II a (non-infected) and II b (infected). The groups were screened for T.vaginalis by direct wet mount, Giemsa, Acridine orange (AO) and Papanicolaou (Pap) stained vaginal smears and culture technique. Cytopathological examination was done by using pap smears. Immunological detection of vaginal IL-2, IL-17, IL-22 and IFN $\gamma$ were assessed using enzyme linked immunosorbent assay (ELISA). The results revealed that the prevalence rate of $T$. vaginalis was $22.5 \%(45 / 200)$ among the studied participants as proved by culture method, $25 \%(25 / 100)$ in asymptomatic females and 20\% (20/100) in symptomatic females. There were significant elevated levels of IL-2, IL-17, IL22 and IFN- $\gamma$ in asymptomatic infected subgroup(Ib) than symptomatic infected subgroup (IIb) and control subgroup and decrease in cytopathological changes including halo cells, reactive nuclear changes and ghost cell. Elevated cytokines play a protective effect in asymptomatic T.vaginalis infected females proved by histopathological inflammatory reaction and decrease symptoms in these females.

\section{Introduction}

Trichomonas vaginalisis a common parasitic protozoan with a cosmopolitan distribution responsible for the sexually transmitted trichomoniasis infection (Graves et al., 2019). The estimated annual incident cases by WHO were 156 million trichomoniasis cases in
2016 all over the world (Rowley et al., 2019). Approximately $80 \%$ of $T$. vaginalis infections are asymptomatic in both women and men (Sutton et al., 2007 \& Poole and Mcclelland, 2013). Asymptomatic infected carriers are the main cause of spreading the infection in their community. 
There were many different clinical signs and $\mathrm{s}$ ymptoms of trichomoniasis depending on each individual immune status, number of infecting trophozoites and pathogenicity of the parasite (Petrin et al., 1998). Symptomatic patients had various symptoms including vaginal discharge and dysuria in women, urethral discharge and dysuria in men (Schwebke \& Burgess, 2004).

Untreated or persistent $T$. vaginalis in women has been associated with infertility, adverse birth out comes and increased risk of human immunodeficiency virus (HIV) transmission (Huppert, 2009 and Meites et al., 2015). Trichomoniasis is considered as one of the predisposing factors for cervical cancer (Depuydt et al., 2010).

Diagnosis of vaginal infections is usually based only on the presence of signs and symptoms. This type of evaluation can lead to misdiagnosis of trichomoniasis as it can be confused with other sexually transmitted diseases (STDs) (Lecke et al., 2003 and Madhivanan et al., 2009). So, laboratory investigations are crucial for diagnosis, to ensure the appropriate treatment and infection control.

Wet mount examination of vaginal fluid has $50-60 \%$ sensitivity rate while the gold standard diagnostic test is the culture technique of vaginal smears (Hobbs and Sena, 2013). Human immune and epithelial cells play an important role in controlling trichomoniasis by production of immunosuppressive cytokines (Han et al., 2009).

Host immune response and comparison between symptomatic and asymptomatic women are important to know the reasons of such pattern of infection and to highlight the possibility of trichomoniasis in the facilitation of HIV transmission (Shafir et al., 2009 and
Hollman et al., 2010). The present study aimed to detect the prevalence rate and risk factors of $T$. vaginalis in asymptomatic and symptomatic females in Menoufia Governorate, Egypt and assess some immunological parameters includingIL-2, IL17, IL-22 and $\mathrm{INF}_{\gamma}$ and their correlation to cytopathological changes in asymptomatic and symptomatic $T$. vaginalis infected women.

\section{Materials and Methods}

\section{Patients and study design}

A cross sectional descriptive study was carried out on 200 females attending to Outpatient Clinics of General Health Center at Shebin Elkom and Obstetric \& Gynaecological Department at Menoufia University, Egypt between May 2018 and July 2019.

All females in this study were married, at the reproductive age and they accepted voluntarily to be enrolled in this study after approval of ethical committee at Faculty of Medicine, Menoufia University.

All females that were below reproductive age, virgin, pregnant, menstruating, with douching or intercourse at the last 2-3 days and those who used antibiotic or anti-protozoal medication for the past 15 days before sampling were excluded from this study.

Information was collected from each woman who voluntarily completed a questionnaire before examination. The questionnaire items included name, age, residence, education, parity, use of contraception, use of treatment, vaginal discharge (color, odor and amount), itching, dysuria, frequency of micturition, lower abdominal pain, backache, dysparonia, vaginal douching, partner symptoms and menstrual regularity. 
The women were classified into two main groups

\section{Group I}

One hundred asymptomatic females with no complaint suggestive of vaginitis but attended to the clinic for other causes not matched with any vaginal complain.

After diagnosis, by culture, this group was subdivided into:

\section{Subgroup I a}

Asymptomatic non-infected, 75 females were negative for $T$. vaginalis from which 10 females were taken as control group for cytokine detection and reexamination of pap stained vaginal smears for cytopathological changes.

\section{Subgroup I b}

Aasymptomatic infected, 25 females were positive for T. vaginalis.

\section{Group II}

One hundred symptomatic women, they complaining of many symptoms suggestive of vaginitis as offensive discharge, dyspareunia, itching, lower abdominal pain, backache, and dysuria. They were also subdivided after diagnosis by culture into:

\section{Subgroup II a}

Symptomatic non-infected, 80 females were negative for $T$. vaginalis.

\section{Subgroup II b}

Symptomatic infected, 20 females were positive for T. vaginalis.

\section{Specimen collection and examination}

\section{Swabs}

From each examined women, three speculum assisted vaginal swabs were taken. The samples were collected from the posterior fornix of the vagina using sterile swabs. Neither lubricant nor antiseptic solution was used. The swab was inserted in the posterior fornix of the vagina and rotated well for proper sample collection (Nassef et al., 2014 and Hussein et al., 2015).

The first swab was placed in one $\mathrm{ml}$ sterile saline solution for wet mount, Giemsa and Acridine orange (AO) staining. The second one was spread on a slide and fixed with $95 \%$ Ethanol for vaginal smear staining by Pap stain (Salih et al., 2017 and Dey, 2018). The third swab was immersed in modified diamond culture media for $T$. vaginalis detection (Diamond et al., 1995). Within one hour, the tubes were transferred to Parasitology Lab, Faculty of Medicine for examination.

Cervicovaginal lavage collection (stute $e t$ al., 2014)

Vaginal lavage samples were collected for cytokines detection by flushing the lateral, anterior, and posterior vaginal walls and fornices of the vagina with $5 \mathrm{~mL}$ of sterile saline using a sterile plastic transfer pipette.

The fluid rapidly collected after 30 seconds. The sample was aspirated and stored in 2 aliquots at $-20^{\circ} \mathrm{c}$ for cytokines detection. Samples that contained blood were excluded.

\section{Smears preparation and examination}

Wet mount smear (Randonjic et al., 2006) was prepared by placing one drop from the sample of the first swap on microscopic glass 
slide then covered by cover slip and examined at $x 100$ and 400 using light microscope.

\section{Giemsa-stained vaginal smear (Garcia, 2001)}

One drop was taken from the first swap tube, then it placed on microscopic glass slide and air dried. The smear fixed by dipping in absolute methanol for $5 \mathrm{~min}$, stained for 20 min at a dilution of 1:20 giemsa stain with phosphate buffer solution.

The slide rinsed gently under running water and allowed to dry in a vertical position. The slide was examined at x1000by light microscope.

\section{Acridine orange stained vaginal smears (Randonjic et al., 2006)}

$50 \mathrm{mg}$ acridine orange powder was dissolved in $10 \mathrm{ml}$ of distilled water to prepare stock solution. This powder was supplied by Sigma Aldrich co, Egypt, with Cat. Number 494-382.

One drop was taken from first swap tube, it was placed on microscopic glass slide, airdried, heat-fixed and stained by AO stain (One $\mathrm{ml}$ of Acridine orange stock solution and $0.5 \mathrm{ml}$ of glacial acetic acid was added to $50 \mathrm{ml}$ of distilled water)for $20 \mathrm{sec}$.

The prepared slides were holded in phosphate buffer solution ( $\mathrm{pH} 7.2)$ at room temperature in the dark until microscopic examination. The slides were examined while they were wet by placing the cover slip and scanned at x400 by fluorescent microscope using selective beam splitter of $510 \mathrm{~nm}$ barrier filter G $247 \mathrm{~nm}$, additional filter of G $249 \mathrm{~nm}$ and excitation filter for narrow band excitation of $255 \mathrm{~nm}$.

The slides examination was performed at Histology Lab, Faculty of Science, Menoufia University, Egypt.
Direct samples examination by Papanicolaou (pap) stained smears (Doshi, 2017)

The second swab was rolled onto two clean slides. The slides were immediately fixed by immersion in a Coplin jar full of $95 \%$ ethanol for a minimum of 30 minutes. The slides were rinsed in tap water then dried in air, immersed in Harris Hematoxylin for 1-3 min then dried in air, rinsed in tap water then dried in air, immersed in $95 \%$ Ethanol for 10 dips then dried in air, immersed in OG-6 stain for 1.5 min then dried in air, immersed in $95 \%$ Ethanol for 10 dips then dried in air, immersed in EA stain for $2.5 \mathrm{~min}$ then dried in air, immersed in $95 \%$ Ethanol for 10 dips then dried in air, 2 changes, cleared in 2 changes of xylene, 2 min each then mounted with permanent mounting medium and examined by x200 and x400. In case of any delay in stain process, the slides were removed from alcohol and air-dried.

\section{Trichomonas vaginalis culture (Diamond $e t$ al., 1995)}

The culture was carried out on diamond's modified medium (Diamond Broth).The components of media include $20 \mathrm{~g}$ pancreatic digest of casein, $10 \mathrm{~g}$ yeast extract, $5 \mathrm{~g}$ maltose, $0.5 \mathrm{~g}$ agar, $1 \mathrm{~g}$ L- cysteine $\mathrm{HCl}, 0.2 \mathrm{~g}$ Lascorbic acid, $0.8 \mathrm{~g}$ dipotassium phosphate, $0.8 \mathrm{~g}$ monopotassium phosphate, 20mg gentamicin, $20 \mathrm{mg}$ vancomycin, $100 \mathrm{ml}$ sterile inactivated horse serum and $950 \mathrm{ml}$ double distilled water. The media was prepared and divided in culture tubes (10ml for each tube) then autoclaved, stored at $+4{ }^{\circ} \mathrm{C}$ in refrigerator and the used tube was first warmed by holding the tube under the arm or in the hand. The third vaginal swab was inoculated into the warmed media and the inoculated tubes were incubated at $37{ }^{\circ} \mathrm{C}$ in an anaerobic incubator for 7 days. Cultured tubes were examined daily by using wet mount method (prepared from the tube sediment using sterile 
Pasteur pipette) and examined using x100 and x400 to detect the motile trophozoites of $T$. vaginalis.

\section{Cytopathological examination}

This step was performed in the Department of Pathology, Faculty of Medicine, Menoufia University.

The degrees of inflammation in examined smears were categorized into three levels: mild inflammation (+ve) (less than 30 inflammatory cells/ high power field), moderate inflammation (++ve) (30 to 100 inflammatory cells/ high-power field) and severe inflammation (+++ve)(more than 100 inflammatory cells/high-power field) (Barouti et al., 2013). Also, the types of inflammatory cells were specialized into halo cells,cannon balls, ghost cells and reactive nuclear changes were also recorded.

Quantitative Estimation of Human IL2, IL17, IL22 and INF $\gamma$ byELISA in vaginal lavage samples(Engvall and Perlmann, 1971)

Quantitative estimation of IL 2, IL17, IL22 and $\mathrm{INF}_{\gamma}$ incervicovaginal wash of positive and control subjects were performed by validated manual microplate ELISA kits in accordance with manufacturer instructions. The kits supplied by Shanghai Sunred Biological Technology Co., Catalogue No. 201-12-0095, 201-12-0039 of IL 2 and 22 respectively and Ray Biotech Co., Catalogue No.ELH-IL17 for IL 17 and abcam Co., Catalogue No. ab46025 for INF $\gamma$. According to standards' concentration and the corresponding optical density $(\mathrm{OD}=450 \mathrm{~nm})$ values, the standard curve linear regression equation was calculated out and the OD values of the sample was applied on the regression equation to calculate the corresponding sample's concentration.

\section{Statistical methods}

Data were statistically analyzed by statistical package SPSS version 22 (Armonk, NY: IBM Corp, 2013). Two types of statistics were done: Descriptive statistics: percentage (\%), mean ( $\mathrm{x})$ and standard deviation (SD).Analytic statistics: Chi-square test $\left(\chi^{2}\right)$, Students t-test, Analysis of variance(ANOVA) test and Kruskall Walklis test were used. Binary logistic regression analysis was performed to examine the independent effects of relevant risk factors of T. vaginalis infection. $\mathrm{P}$-value of $\leq 0.05$ was considered statistically significant.

\section{Results and Discussion}

A total of two hundreds non pregnant women from Menoufia Governorate were enrolled into this study (asymptomatic, $\mathrm{n}=100$; symptomatic, $\mathrm{n}=100)$. The prevalence rate of T. vaginalis was $22.5 \%(45 / 200)$ among the studied participants by culture technique. The prevalence rate among asymptomatic women was $25 \%$ while among symptomatic women it was $20 \%$ (Table 1 ).

The wet mount prepared smears and cultures showed trophozoite of $T$. vaginalis $(15-30 \mu \mathrm{m})$ with their characteristic morphological feature and jerky motility (Fig.1a). Violet, pearshaped trophozoites showing flagella and undulating membrane with anterior nucleus were detected inGiemsa-stained vaginal smears (Fig.1b).In Acridine orange stained vaginal smears, $T$. vaginalis trophozoite stained deeply red with a yellowish banana or rounded nucleus (Fig.1c).

Pap stained vaginal smears showed oval and grey color $T$. vaginalis trophozoite (15-30 $\mu \mathrm{m})$ with characteristic flagella and nucleus (Fig.1d). The sensitivities of different diagnostic methods were estimated in relation to culture method (gold standard test) (Table 2). The higher sensitivity rate and accuracy 
were recorded by Acridine orange stain (76\% and $94 \%$ respectively) followed by Giemsa stain (67\% and $93 \%$ respectively).The least sensitivity and accuracy rates were recorded by pap stain (38\% and $81 \%$ ) respectively (Table 2). The groups were described as regards their ages, education and residence. There was significant difference between infected and noninfected females in regularity of cycle, use of vaginal douching, presence of partner symptoms ( $\mathrm{p}$ value of $<0.001^{* *}$, $<0.001 * *, 0.001 * *$ respectively) (Table 3 ).

The binary regression analysis showed that the risk factors for $T$. vaginalis infection in the studied participants were nearly increased 16 times in presence of partners' symptoms than those with asymptomatic partners $(\mathrm{P} \leq$ 0.001), also women used vaginal douches were nearly had 6 times higher risk for acquiring $T$. vaginalis infection than women not using it $(\mathrm{P} \leq$ 0.006) (Table 4). The cytopathological changes were detected by pap stained vaginal smears, the infected women showed presence of halo cells, reactive nuclear changes, cannon balls and ghost cells.

The higher percentage of $90 \%$ were recorded as halo cells and cannon balls in symptomatic infected subgroup (II b) while reactive nuclear changes were noticed in $80 \%$ with higher rate $(70 \%)$ of moderate inflammation reaction (Table 5). These cytopathological changes were more prevalent in symptomatic infected subgroup (II b) (Fig.2 a, b, c, d, e \&f) than asymptomatic infected subgroup (I b) (Fig. 3 a, b, c \& d) (Table 5).

Regarding vaginal cytokines levels in $T$. vaginalis infected females, the higher mean levels of IL-2, IL-17, IL-22 and $\mathrm{INF}_{\gamma}$ were detected in asymptomatic infected subgroup (I b) than symptomatic infected subgroup (II b) and the lower level were detected in control group $(\mathrm{P} \leq 0.001)$ (Graph 1). There were significantly higher mean levels of IL-2 and INF $\gamma$ with negative halo cells and negative ghost cells $(\mathrm{P}<0.05)$ in infected subgroups(I b\& II b) (Table 6).

There were also significantly lower mean levels of both IL-17 and IL-22 in the presence of halo cells $(\mathrm{P}<0.05)$ and reactive nuclear changes $(\mathrm{P}<0.05)$ in infected subgroups $(\mathrm{I} b \&$ II b) (Table 6). The mean levels of IL-2 and INF $\gamma$ were significantly lower with increased severity of inflammation in the same subgroups $(\mathrm{P}<0.05)$ (Graph 2). Also, there were significantly higher mean levels of IL17 and IL-22 in mild inflammation than in moderate inflammation and severe inflammation $(\mathrm{P}<0.05)$ in infected subgroups (I b\& II b)(Graph 2).

In the present study, the prevalence rate of $T$. vaginalis was evaluated between asymptomatic and symptomatic females attending to Outpatient Clinics of General Health Center at Shebin Elkom and Obstetric \& Gynaecological Department at Menoufia University, Egypt. The prevalence rate was $22.5 \%(45 / 200)$ by culture method.

This rate was agreed with Elsherif and Youssef (2013), Nassef et al., (2014) and ElGayar et al., (2016), they found prevelance rate of $23 \%, 35.3 \%, 37.7 \%$ respectively in Mansoura, Menoufiya and Ismailia Governorate by using PCRand culture techniques. While Abou-kamar et al., (2017) and Hamdy and Hamdy (2018) were recorded lower prevalence rate of $13 \%$ and $8 \%$ in ElMansoura and Beni-Suef cities respectively by using culture and latex agglutination test. The wide world prevalence among suspected females ranges from $0.9 \%$ to $80 \%$ (Valadkhani et al., 2008 and Javanbakht et al., 2013). Despite the variation of prevalence, it is known that infection rates are usually higher in developing countries, depending on the scope and quality of health 
care, socioeconomic conditions, and educational status of the population (Siracusano et al., 2014). In the current work, the prevalence rate of $T$. vaginalis was $25 \%$ (25/100) in asymptomatic (Group I) and 20\% (20/100) in symptomatic (Group II) by culture method.

These results were agreed withthat recorded by Valadkhani et al., (2008), who reported higher prevalence among asymptomatic females than symptomatic ones $(1.1 \%$ and $0.8 \%$ respectively). While Nassef et al., (2014), Ton et al., (2015), Abou-kamar et al., (2017) and Nicholls et al., (2018) reported that the prevalence was more in symptomatic cases $(38.1 \%, 19.3 \%, 22 \%$ and $2.9 \%$ respectively) than asymptomatic (27.3\%, $0.7 \%, 5 \%$ and $1.3 \%$ respectively) ones.

The presence of signs and symptoms, though supporting the diagnosis of trichomoniasis, cannot be used alone to achieve an accurate diagnosis. Also, lack of symptoms does not exclude the possibility of infection(Alves $e t$ al., 2011).In this study, there were 34 (17\%), 30 (15\%), 27 (13.5\%), 26 (13\%) positive cases out of 200 cases by Acridine orange, Giemsa, pap staining and wet mount respectively with sensitivities of $76 \%, 67 \%$, $38 \%$ and $58 \%$ and specificities of $100 \%$, $100 \%, 100 \%$ and $93.5 \%$ respectively with accuracy rate of $94 \%, 93 \%, 81 \%$ and $91 \%$ respectively in comparison with culture as the gold standard in diagnosis of $T$. vaginalis infection (Caliendo et al., 2005 and Schwebke, 2005).

These results were in accordance with Gavgani et al., (2008), Aboulghar et al., (2009), Zaki et al (2011), Patil et al., (2012), Nassef et al., (2014), Mahmoud et al., (2015) and Hussein et al., (2015) who showed that culture method was more sensitive than wet mount. In this study, Pap staining method has the same prevalence rate $(13.5 \%)$ as wet mount one $(13 \%)$. This comes in agreement with Hagag et al., (2019) who reported $16 \%$ prevalence of trichomoniasis by pap stain.

In the current work, there was significant association between $T$. vaginalis infection and cycle irregularity, using vaginal douches and presence of partners' symptoms with ( $p$ $<0.001$ ) for each of them respectively. Herein the presence of partners' symptoms significantly increases the risk of acquiring $T$. vaginalis infection 16 times more than those women whose partners are symptoms free $(\mathrm{p}<$ 0.001).Men act as a reservoir for the infection and can transmit infection to their wife or partners (Crucitti et al., 2011).

Moreover, the women used vaginal douches had significantly 6 times higher risk of acquiring $T$. vaginalis infection than those who are not using it. These results were in agreement with that the vaginal douching changes $\mathrm{pH}$ of vagina, decrease acidity and eliminate vaginal lactobacilli and these changes predispose to bacterial vaginosis (BV) (Ranjit et al., 2018). These results were also coincide with that reported by Tineet al., (2019), who found that $59 \%$ of $T$. vaginalis positive women have a type 4 vaginal microbiome which includes strict anaerobic bacteria as Mycoplasma and decrease in Lactobacilli which increase $\mathrm{pH}$ of vagina.

In the present study, by using pap stain for examination of the cytopathological changes, it showed cannon balls, perinuclear halo, reactive nuclear changes and ghost cells in infected females with percentage of $82 \%$, $75 \%, 64 \%$ and $53 \%$ respectively. These results were in agreement with Noël and Engohan- Aloghe (2010) who reported that the presence of cannonballs, perinuclear halo, reactive nuclear changes associated with $T$. vaginalis infection with percentage of $(93 \%$, $90 \%$ and $88 \%$ respectively) and Hagag et al., (2019) who found that the presence of 
perinuclear halo was present in $62 \%$ of $T$. vaginalis positive females. The present results cleared that the presence of halo cells, reactive nuclear changes and ghost cells were less prevalent in asymptomatic infected subgroup (I b) than symptomatic infected subgroup (II b) with percent of $64 \%, 52 \%$, $40 \%$ among asymptomatic versus $90 \%, 80 \%$, $70 \%$ among symptomatic respectively.

These cytopathological changes may explained by $T$. vaginalis nutrition habits as it derives nutrients from lysing and feeding on host cells causing necrosis of epithelial cells rather than induction of apoptosis thus converting epithelial cells into ghost cells (Ryan et al., 2011 and Lustig et al., 2013). The mean levels of all cytokines (IL2, IL17 and IL22) and $\mathrm{INF}_{\gamma}$ were significantly elevated in asymptomatic infected subgroup (I b) than symptomatic infected subgroup (II b) $(\mathrm{p} \leq 0.001)$.

These results agreed with that reported by Malla et al., (2007) who reported that elevation of IL $2(\mathrm{P}<0.001)$ and INFy $(\mathrm{P}<$ $0.05)$ in mice infected by asymptomatic $T$. vaginalis isolates than symptomatic ones. Also, Jha et al., (2011) explained the elevation of cytokines (IL-17 and IL-22) by that they are induced by similar stimuli and both are made by $\mathrm{T}$ helper cell subsets. Elevated levels of cytokines (IL17 \& IL22) in asymptomatic infected females produce a protective role and control the symptoms of $T$. vaginalis (Makinde et al., 2013 andValeri and Raffatellu, 2016).

Similarly Zheng et al., (2008) and Feng et al., (2009) explained that protective role of IL-17 and IL-22 by production of antimicrobial peptides, which is largely dependent on the synergistic action of IL-17 and IL-22 on epithelial cells. Also, Albanesi et al., (2000) and Nograles et al., (2008) explained that protective role of IL-17 and IL-22byinduction of epithelial cells to express chemokines that attract granulocytes, particularly neutrophils, to sites of infection. In the present study a lower cytopathological changes were detected in the presence of elevated level of IL-2, IL17, IL-22 cytokines and INF $\gamma$. Herein, the mean level of IL-2 and INF ${ }_{\gamma}$ were significantly lowered with increased severity of inflammation in symptomatic infected subgroup (II b) and there were significantly higher mean levels of IL-2 and INF $\gamma$ with negative Halo cells and negative ghost cells in infected women. These results may explained with, the high level of Th1 type cytokines IL2 and IFN- $\gamma$ in asymptomatic infected females as compared to symptomatic infected females might be playing a role in maintaining low levels of infection (Malla et al., 2007). Also, Paintlia et al., (2002) reported that IFN- $\gamma$ has been proved to increase macrophage mediated cytotoxity against $T$. vaginalis and played a role in elimination or suppression of proliferation of $T$. vaginalis. From the present results, it is cleared that the elevated mean levels of cytokines is associated with decrease inflammation degrees. These results agreed with Schwebke and Burgess (2004), who reported that T.vaginalis causes epithelial damage and IL-22 plays a protective role against this damage. The functions of IL17and IL-22 are very important in maintaining mucosal immunity against specific pathogens and enhancement of mucosal barrierrepair by stimulating epithelial cell proliferation and tight junction protein production (Zheng et al., 2008, Conti et al., 2009 and Pickert et al., 2009). In the present work, the cytopathological examination revealed that the most prominent cells were lymphocytes in asymptomatic infected subgroup (I b) where IL-17 and IL-22 elevated. 
Table.1 The prevalence rate of $T$. vaginalis infection in studied groups by different diagnostic methods

\begin{tabular}{|c|c|c|c|c|c|}
\hline Items & $\begin{array}{c}\text { GroupI } \\
\text { (Asymptomatic) } \\
(\mathbf{n}=\mathbf{1 0 0}) \\
\text { No }(\%)\end{array}$ & $\begin{array}{c}\text { GroupII } \\
\text { (Symptomatic) } \\
(\mathbf{n}=\mathbf{1 0 0}) \\
\text { No }(\%)\end{array}$ & $\begin{array}{c}\text { Total } \\
(\mathbf{n}=200) \\
\text { No }(\%)\end{array}$ & $\chi^{2}$ & $\begin{array}{c}\text { p- } \\
\text { value }\end{array}$ \\
\hline $\begin{array}{l}\text { Wet mount: } \\
\text { Positive } \\
\text { Negative }\end{array}$ & $\begin{array}{ll}15 & (15.0) \\
85 & (85.0)\end{array}$ & $\begin{array}{ll}11 & (11.0) \\
89 & (89.0)\end{array}$ & $\begin{array}{c}26(13.0) \\
174(87.0)\end{array}$ & 0.71 & 0.400 \\
\hline $\begin{array}{l}\text { Giemsa stain: } \\
\text { Positive } \\
\text { Negative }\end{array}$ & $\begin{array}{ll}17 & (17.0) \\
83 & (83.0)\end{array}$ & $\begin{array}{ll}13 & (13.0) \\
87 & (87.0)\end{array}$ & $\begin{array}{c}30(15.0) \\
170(85.0)\end{array}$ & 0.63 & 0.428 \\
\hline $\begin{array}{c}\text { Acridine orange: } \\
\text { Positive } \\
\text { Negative }\end{array}$ & $\begin{array}{ll}19 & (19.0) \\
81 & (81.0)\end{array}$ & $\begin{array}{ll}15 & (15.0) \\
85 & (85.0)\end{array}$ & $\begin{array}{c}34(17.0) \\
166(83.0)\end{array}$ & 0.57 & 0.451 \\
\hline $\begin{array}{l}\text { Pap stain: } \\
\text { Positive } \\
\text { Negative }\end{array}$ & $\begin{array}{ll}10 & (10.0) \\
90 & (90.0)\end{array}$ & $\begin{array}{ll}17 & (17.0) \\
83 & (83.0)\end{array}$ & $\begin{array}{c}27(13.5) \\
173(86.5)\end{array}$ & 2.10 & 0.147 \\
\hline $\begin{array}{l}\text { Culture: } \\
\text { Positive } \\
\text { Negative }\end{array}$ & $\begin{array}{ll}25 & (\mathbf{2 5 . 0}) \\
75 & (75.0)\end{array}$ & $\begin{array}{ll}20 & (\mathbf{2 0 . 0}) \\
80 & (80.0)\end{array}$ & $\begin{array}{l}45(\mathbf{2 2 . 5}) \\
155(77.5)\end{array}$ & 0.72 & 0.397 \\
\hline
\end{tabular}

Table. 2 Comparison between different methods of diagnosis of $T$. vaginalis infection as regard to culture in the studied females

\begin{tabular}{|c|c|c|c|c|c|c|c|}
\hline \multirow{2}{*}{$\begin{array}{c}\text { Items } \\
(n=200)\end{array}$} & \multicolumn{2}{|c|}{ Culture method $(n=200)$} & \multirow[t]{2}{*}{ Sensitivity } & \multirow[t]{2}{*}{ Specificity } & \multirow[t]{2}{*}{ Accuracy } & \multirow[t]{2}{*}{ PPV } & \multirow[t]{2}{*}{ NPV } \\
\hline & $\begin{array}{c}\text { Positive } \\
(n=45) \\
\text { No }(\%)\end{array}$ & $\begin{array}{c}\text { Negative } \\
(n=155) \\
\text { No }(\%)\end{array}$ & & & & & \\
\hline $\begin{array}{c}\text { Wet mount: } \\
\text { Positive } \\
\text { Negative }\end{array}$ & $\begin{array}{l}26(57.8) \\
19(42.2)\end{array}$ & $\begin{array}{c}0 \\
155(100.0)\end{array}$ & $58 \%$ & $100 \%$ & $91 \%$ & $100 \%$ & $89 \%$ \\
\hline $\begin{array}{c}\text { Giemsa stain: } \\
\text { Positive } \\
\text { Negative }\end{array}$ & $\begin{array}{l}30(66.7) \\
15(33.3) \\
\end{array}$ & $\begin{array}{c}0 \\
155(100.0)\end{array}$ & $67 \%$ & $100 \%$ & $93 \%$ & $100 \%$ & $91 \%$ \\
\hline $\begin{array}{l}\text { Acridine } \\
\text { orange: } \\
\text { Positive } \\
\text { Negative }\end{array}$ & $\begin{array}{l}34(75.6) \\
11(24.4)\end{array}$ & $\begin{array}{c}0 \\
155(100.0)\end{array}$ & $76 \%$ & $100 \%$ & $94 \%$ & $100 \%$ & $93 \%$ \\
\hline $\begin{array}{l}\text { Pap stain: } \\
\text { Positive } \\
\text { Negative }\end{array}$ & $\begin{array}{l}17(37.8) \\
28(62.2)\end{array}$ & $\begin{array}{c}10 \\
145(93.5)\end{array}$ & $38 \%$ & $93.5 \%$ & $81 \%$ & $63 \%$ & $84 \%$ \\
\hline
\end{tabular}

PPV: positive predictive value

NPV: negative predictive value 
Table.3 Sociodemographic characteristics of infected and non-infected females

\begin{tabular}{|c|c|c|c|c|c|}
\hline Item & $\begin{array}{c}\text { Infected females } \\
(\mathbf{N}=45) \\
\text { No }(\%)\end{array}$ & 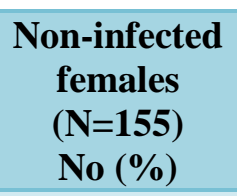 & $\chi^{2}$ & p-value & OR $(95 \%$ CI $)$ \\
\hline $\begin{array}{l}\text { Age (years) } \\
\text { A }(18-34) \\
\text { B (35-50) }\end{array}$ & $\begin{array}{l}25(55.6) \\
20(44.4)\end{array}$ & $\begin{array}{c}107(69.0) \\
48(31.0)\end{array}$ & 2.82 & 0.093 & $\begin{array}{c}0.56 \\
(0.284-1.106)\end{array}$ \\
\hline $\begin{array}{c}\text { Education levels: } \\
\text { Educated } \\
\text { Illiterate }\end{array}$ & $\begin{array}{l}28(62.2) \\
17(37.8)\end{array}$ & $\begin{array}{c}106(68.4) \\
49(31.6)\end{array}$ & 0.60 & 0.439 & $\begin{array}{c}0.76 \\
(0.381-1.520)\end{array}$ \\
\hline $\begin{array}{l}\text { Residence: } \\
\text { Rural } \\
\text { Urban }\end{array}$ & $\begin{array}{l}34(75.6) \\
11(24.4)\end{array}$ & $\begin{array}{c}116(74.8) \\
39(25.2)\end{array}$ & 0.01 & 0.922 & $\begin{array}{c}1.04 \\
(0.481-2.246)\end{array}$ \\
\hline $\begin{array}{l}\text { Cycle regularity: } \\
\text { Regular } \\
\text { Irregular }\end{array}$ & $\begin{array}{l}28(62.2) \\
17(37.8)\end{array}$ & $\begin{array}{c}155(100.0) \\
0\end{array}$ & 64.0 & $<0.001 * *$ & $\begin{array}{c}0.65 \\
(4.65-9.19)\end{array}$ \\
\hline $\begin{array}{c}\text { Parity } \\
\text { Nullipara } \\
\text { Multipara }\end{array}$ & $\begin{array}{c}7(15.6) \\
38(84.4)\end{array}$ & $\begin{array}{c}26(16.8) \\
129(83.2)\end{array}$ & 0.04 & 0.846 & $\begin{array}{c}0.91 \\
(0.368-2.270)\end{array}$ \\
\hline $\begin{array}{c}\text { Vaginal douching: } \\
\text { Yes } \\
\text { No }\end{array}$ & $\begin{array}{l}23(51.1) \\
22(48.9)\end{array}$ & $\begin{array}{c}6(3.9) \\
149(96.1)\end{array}$ & 62.78 & $<0.001 * *$ & $\begin{array}{c}0.04 \\
(0.014-0.105)\end{array}$ \\
\hline $\begin{array}{c}\text { Types of } \\
\text { contraception: } \\
\text { Not used } \\
\text { Condom } \\
\text { Hormonal } \\
\text { IUDs }\end{array}$ & $\begin{array}{c}4(8.9) \\
1(2.2) \\
25(55.6) \\
15(33.3)\end{array}$ & $\begin{array}{c}13(8.4) \\
7(4.5) \\
69(44.5) \\
66(42.6)\end{array}$ & $\begin{array}{l}1.46 \\
0.48 \\
1.91 \\
1.24\end{array}$ & $\begin{array}{l}0.227 \\
0.489 \\
0.167 \\
0.266\end{array}$ & $\begin{array}{l}1.83(0.71-4.70) \\
0.48(0.06-4.01) \\
1.60(0.82-3.12) \\
0.67(0.34-1.35)\end{array}$ \\
\hline $\begin{array}{c}\text { Partner' symptoms } \\
\text { Present } \\
\text { Absent }\end{array}$ & $\begin{array}{l}10(22.2) \\
35(77.8)\end{array}$ & $\begin{array}{c}3(1.9) \\
152(98.1)\end{array}$ & 23.62 & $<0.001 * *$ & $\begin{array}{c}0.07 \\
(0.018-0.264)\end{array}$ \\
\hline
\end{tabular}

OR: Odd's Ratio $\quad$ CI: confidence interval $\quad \mathrm{P} \leq 0.001 * *$ is considered highly significant relation

Table.4 Binary logistic regression analysis (B) for relevant risk factors for T. vaginalis infection in studied participants

\begin{tabular}{|l|c|c|c|c|c|}
\hline \multicolumn{1}{|c|}{ Variables } & B & p-value & OR & \multicolumn{2}{c|}{ 95\% C.I } \\
\hline $\begin{array}{l}\text { Use of vaginal } \\
\text { douches }\end{array}$ & 1.823 & $\mathbf{0 . 0 0 6 *}$ & 6.19 & 1.667 & 22.994 \\
\hline $\begin{array}{l}\text { Presence of } \\
\text { partners' } \\
\text { symptoms }\end{array}$ & 2.760 & $\mathbf{0 . 0 0 1 * *}$ & 15.80 & 3.627 & 68.820 \\
\hline
\end{tabular}

B: Binary logistic regression analysis

$\mathrm{P} \leq 0.001 * *$ is considered highly significant relation

$\mathrm{P} \leq 0.05 *$ is considered significant relation 
Table.5 Cytopathological response in asymptomatic (Subgroup I b) and symptomatic (Subgroup II b) infected females

\begin{tabular}{|c|c|c|c|c|c|}
\hline \multirow[t]{2}{*}{ Items } & \multicolumn{3}{|c|}{ Infected females $(n=45)$} & \multirow[t]{2}{*}{$\chi^{2}$} & \multirow[t]{2}{*}{ p-value } \\
\hline & $\begin{array}{c}\text { Subgroup I b } \\
(n=25) \\
(\%)\end{array}$ & $\begin{array}{c}\text { Subgroup II b } \\
\left(\begin{array}{c}\mathbf{n}=\mathbf{2 0}) \\
(\%)\end{array}\right.\end{array}$ & $\begin{array}{c}\text { Total }(\mathrm{n}=45) \\
(\%)\end{array}$ & & \\
\hline $\begin{array}{l}\text { Halo cells: } \\
\text { +ve } \\
\text {-ve }\end{array}$ & $\begin{array}{l}16(64.0) \\
9(36.0)\end{array}$ & $\begin{array}{c}18(90.0) \\
2(10.0)\end{array}$ & $\begin{array}{l}34(75.6) \\
11(24.4)\end{array}$ & 4.07 & $0.044 *$ \\
\hline $\begin{array}{c}\text { Reactive nuclea } \\
\text { changes: } \\
\text { +ve } \\
\text {-ve }\end{array}$ & $\begin{array}{l}13(52.0) \\
12(48.0)\end{array}$ & $\begin{array}{c}16(80.0) \\
4(20.0)\end{array}$ & $\begin{array}{l}29(64.4) \\
16(35.6)\end{array}$ & 3.80 & $0.05 *$ \\
\hline $\begin{array}{c}\text { Cannon balls: } \\
\text { +ve } \\
\text {-ve }\end{array}$ & $\begin{array}{c}19(76.0) \\
6(24.0)\end{array}$ & $\begin{array}{c}18(90.0) \\
2(10.0)\end{array}$ & $\begin{array}{l}37(82.2) \\
8(17.8)\end{array}$ & 1.49 & 0.222 \\
\hline $\begin{array}{c}\text { Ghost cells: } \\
\text { +ve } \\
\text {-ve }\end{array}$ & $\begin{array}{l}10(40.0) \\
15(60.0)\end{array}$ & $\begin{array}{c}14(70.0) \\
6(30.0)\end{array}$ & $\begin{array}{l}24(53.3) \\
21(46.7)\end{array}$ & 4.02 & $0.045 *$ \\
\hline $\begin{array}{c}\text { Trichomonas } \\
\text { trophozoite: } \\
\text { +ve } \\
\text {-ve }\end{array}$ & $\begin{array}{l}10(40.0) \\
15(60.0)\end{array}$ & $\begin{array}{c}7(35.0) \\
13(65.0)\end{array}$ & $\begin{array}{l}17(37.8) \\
28(62.2)\end{array}$ & 0.12 & 0.731 \\
\hline $\begin{array}{l}\text { Coccobacilli: } \\
\text { +ve } \\
\text {-ve }\end{array}$ & $\begin{array}{l}12(48.0) \\
13(52.0)\end{array}$ & $\begin{array}{c}14(70.0) \\
6(30.0)\end{array}$ & $\begin{array}{l}26(57.8) \\
19(42.2)\end{array}$ & 2.10 & 0.138 \\
\hline $\begin{array}{c}\text { Degree of } \\
\text { inflammation: } \\
\text { Mild }(+) \\
\text { Moderate }(++) \\
\text { Severe }(+++)\end{array}$ & $\begin{array}{c}10(40.0) \\
12(48.0) \\
3(12.0)\end{array}$ & $\begin{array}{c}2(10.0) \\
14(70.0) \\
4(20.0)\end{array}$ & $\begin{array}{c}12(26.7) \\
26(57.8) \\
7(15.6)\end{array}$ & 5.14 & 0.077 \\
\hline
\end{tabular}


Table.6 Relation between vaginal levels of IL-2, IL-17, IL-22 \& INF $\gamma$ and cytopathological changes in infected subgroups (I b \& II b)

\begin{tabular}{|c|c|c|c|c|c|c|c|c|c|}
\hline & & \multicolumn{8}{|c|}{ Cytopathological changes } \\
\hline \multirow{2}{*}{\multicolumn{2}{|c|}{ Cytokines }} & \multicolumn{2}{|c|}{ Halo cells } & \multicolumn{2}{|c|}{$\begin{array}{c}\text { Reactive } \mathbf{N} . \\
\text { changes }\end{array}$} & \multicolumn{2}{|c|}{ Cannon balls } & \multicolumn{2}{|c|}{ Ghost cell } \\
\hline & & $+v e$ & -ve & $+\mathrm{ve}$ & -ve & +ve & -ve & +ve & -ve \\
\hline IL-2 & $\begin{array}{c}\text { Mean } \pm \\
\text { SD }\end{array}$ & $\begin{array}{c}16.33 \pm \\
6.09\end{array}$ & $\begin{array}{c}21.20 \pm \\
5.78\end{array}$ & $\begin{array}{c}16.33 \pm \\
6.21\end{array}$ & $\begin{array}{c}19.67 \pm \\
6.12\end{array}$ & $\begin{array}{c}17.00 \pm \\
6.20\end{array}$ & $\begin{array}{c}19.91 \pm \\
6.71\end{array}$ & $\begin{array}{c}15.49 \pm \\
5.37\end{array}$ & $\begin{array}{c}19.84 \pm \\
6.64\end{array}$ \\
\hline & $\begin{array}{l}\text { t- test } \\
\text { P-value }\end{array}$ & \multicolumn{2}{|c|}{$\begin{array}{c}2.33 \\
\text { 0.024* }\end{array}$} & \multicolumn{2}{|c|}{$\begin{array}{c}1.73 \\
0.090\end{array}$} & \multicolumn{2}{|c|}{$\begin{array}{c}1.19 \\
0.242\end{array}$} & \multicolumn{2}{|c|}{$\begin{array}{c}2.43 \\
\text { 0.019* }\end{array}$} \\
\hline \multirow[t]{2}{*}{ IL-17 } & $\begin{array}{c}\text { Mean } \pm \\
\text { SD }\end{array}$ & $\begin{array}{l}103.30 \\
\pm 22.54\end{array}$ & $\begin{array}{l}129.42 \\
\pm 21.62\end{array}$ & $\begin{array}{l}103.49 \\
\pm 23.53\end{array}$ & $\begin{array}{l}120.93 \\
\pm 33.77\end{array}$ & $\begin{array}{c}105.26 \pm \\
23.53\end{array}$ & $\begin{array}{c}130.14 \pm \\
21.05\end{array}$ & $\begin{array}{c}100.65 \pm \\
20.46\end{array}$ & $\begin{array}{c}120.00 \pm \\
25.78\end{array}$ \\
\hline & $\begin{array}{l}\text { t- test } \\
\text { P value }\end{array}$ & \multicolumn{2}{|c|}{3.37} & \multicolumn{2}{|c|}{2.37} & \multicolumn{2}{|c|}{2.76} & \multicolumn{2}{|c|}{2.81} \\
\hline \multirow[t]{2}{*}{ IL-22 } & $\begin{array}{c}\text { Mean } \pm \\
\text { SD }\end{array}$ & $\begin{array}{c}56.55 \pm \\
14.90\end{array}$ & $\begin{array}{l}71.6 \pm \\
11.79\end{array}$ & $\begin{array}{c}55.7 \pm \\
14.8\end{array}$ & $\begin{array}{c}68.3 \pm \\
13.6\end{array}$ & $\begin{array}{c}58.49 \pm 1 \\
5.49\end{array}$ & $\begin{array}{c}68.29 \pm \\
13.80\end{array}$ & $\begin{array}{c}57.86 \pm 1 \\
7.18\end{array}$ & $\begin{array}{c}62.94 \pm \\
13.27\end{array}$ \\
\hline & $\begin{array}{c}\text { t- test } \\
\text { P-value }\end{array}$ & \multicolumn{2}{|c|}{3.05} & \multicolumn{2}{|c|}{2.81} & \multicolumn{2}{|c|}{1.65} & & \\
\hline \multirow[t]{2}{*}{$\mathrm{INF}_{v}$} & $\begin{array}{c}\text { Mean } \pm \\
\text { SD }\end{array}$ & $\begin{array}{c}83.21 \pm \\
14.50\end{array}$ & $\begin{array}{c}94.25 \pm \\
11.77\end{array}$ & $\begin{array}{c}82.89 \pm \\
14.35\end{array}$ & $\begin{array}{c}91.36 \pm \\
13.75\end{array}$ & $\begin{array}{c}84.75 \pm \\
14.48\end{array}$ & $\begin{array}{c}91.24 \pm \\
14.72\end{array}$ & $\begin{array}{c}81.54 \pm \\
13.25\end{array}$ & $\begin{array}{c}90.89 \pm \\
14.70\end{array}$ \\
\hline & $\begin{array}{l}\text { t- test } \\
\text { P-value }\end{array}$ & \multicolumn{2}{|c|}{$0.027 *$} & 0.061 & & & & $0.030 *$ & 3* \\
\hline
\end{tabular}

$\mathrm{P} \leq 0.001 * *$ is considered highly significant relation

$\mathrm{P} \leq 0.05^{*}$ is considered significant relation 


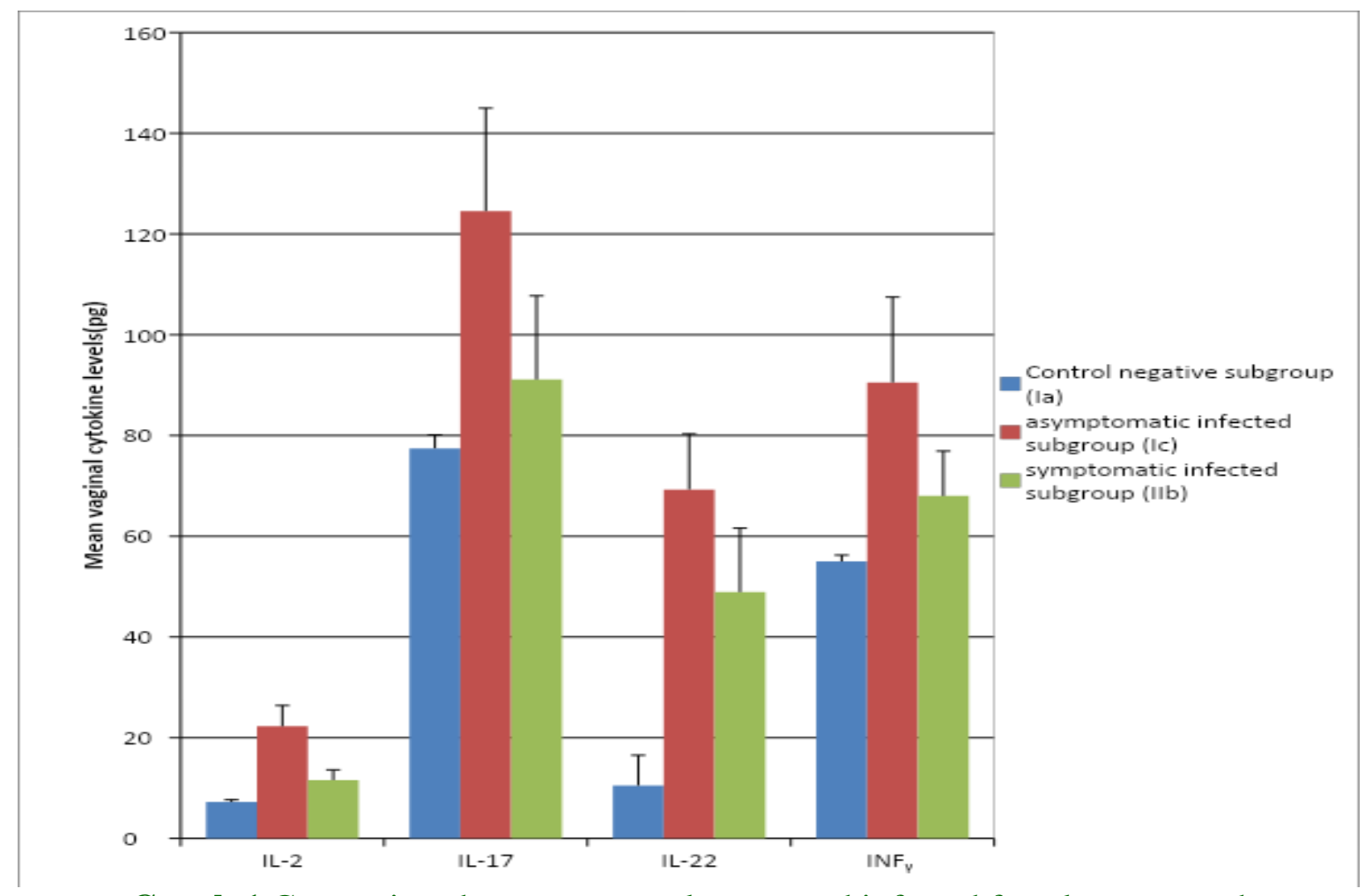

Graph.1 Comparison between control group and infected females as regard vaginal cytokines levels $(\mathrm{P} \leq 0.001)$

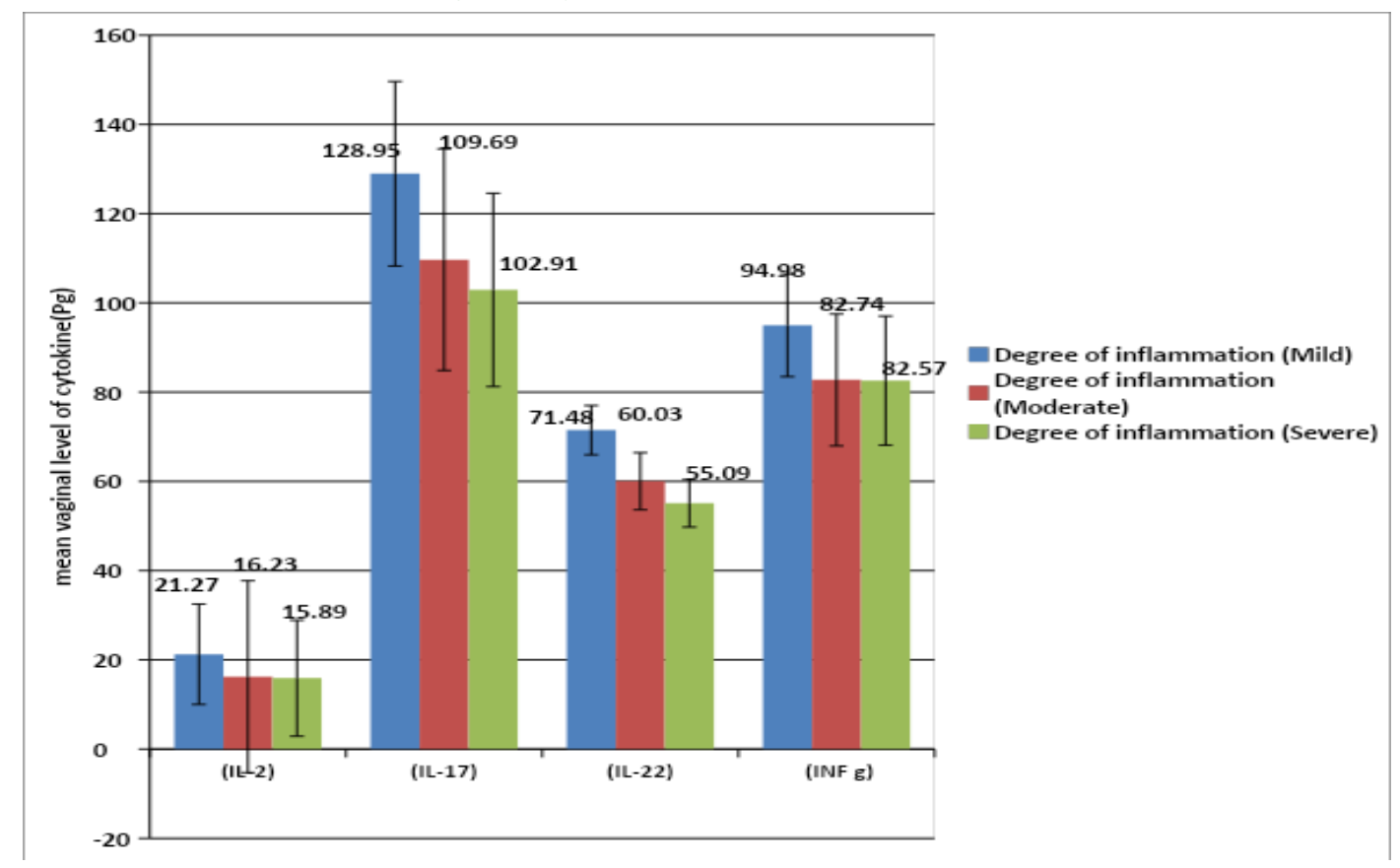

Mild inflammatory reaction $(+)$

Moderate inflammatory reaction (++)

Severe inflammatory reaction $(+++)$

Graph.2 Relation between vaginal levels of IL-2, IL-17, IL-22 and $\mathrm{INF}_{\gamma}$ and degree of inflammation in infected subgroups (I b \& II b) 

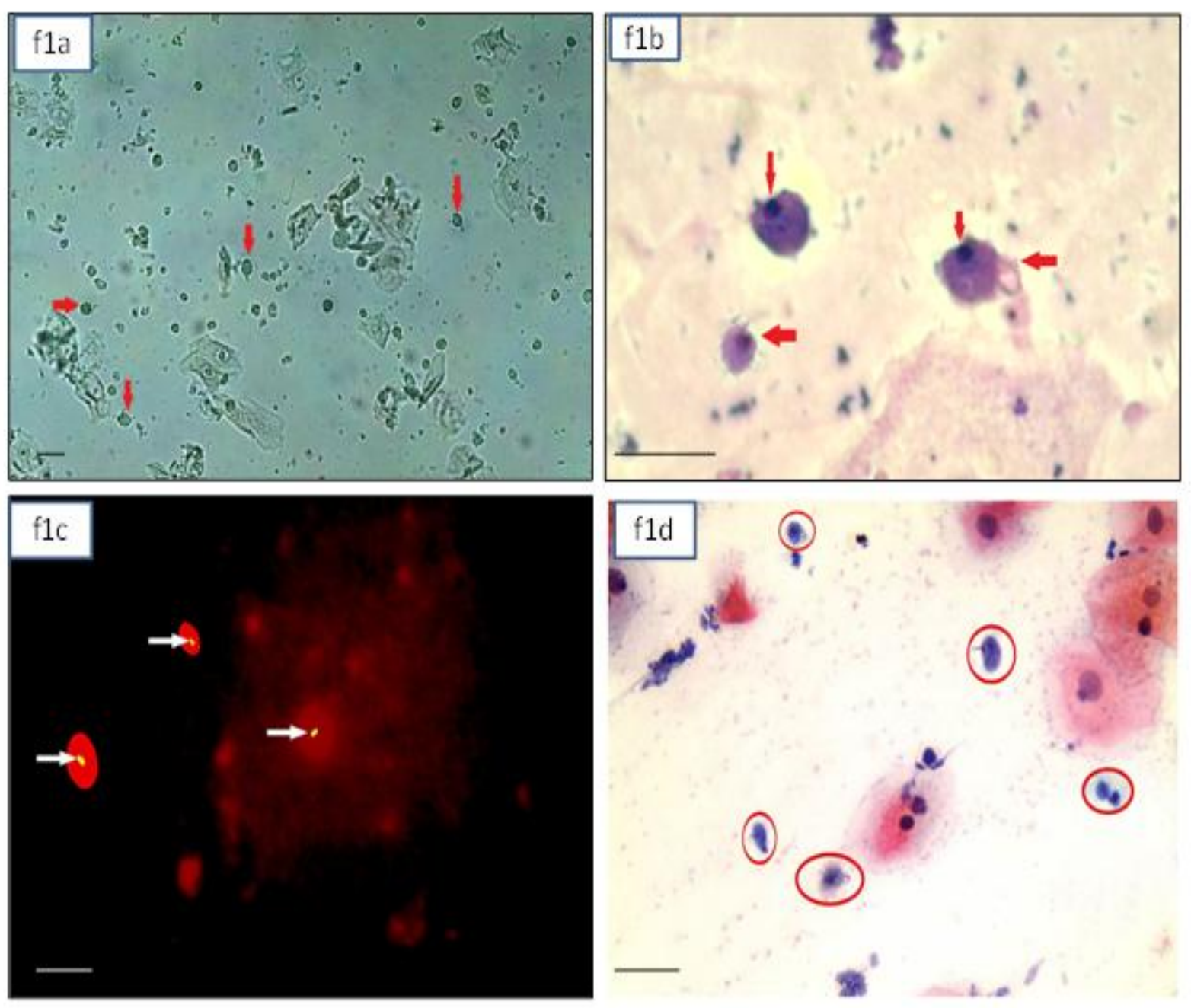

Fig.1a Wet mount smear showing T. vaginalis trophozite with anterior nucleus and flagella (x10)

Fig.1b Giemsa stain vaginal smear showing $T$. vaginalis trophozoite with anterior nucleus and flagella (x 100)

Fig.1c Acridine Orange stained vaginal smear showing red T. vaginalis trophozoite with central yellow banana shaped nucleus (x 40)

Fig.1d Pap stained vaginal smear showing oval grey color T. vaginalis trophozoite (red circles) with flagella and nucleus (x40) 


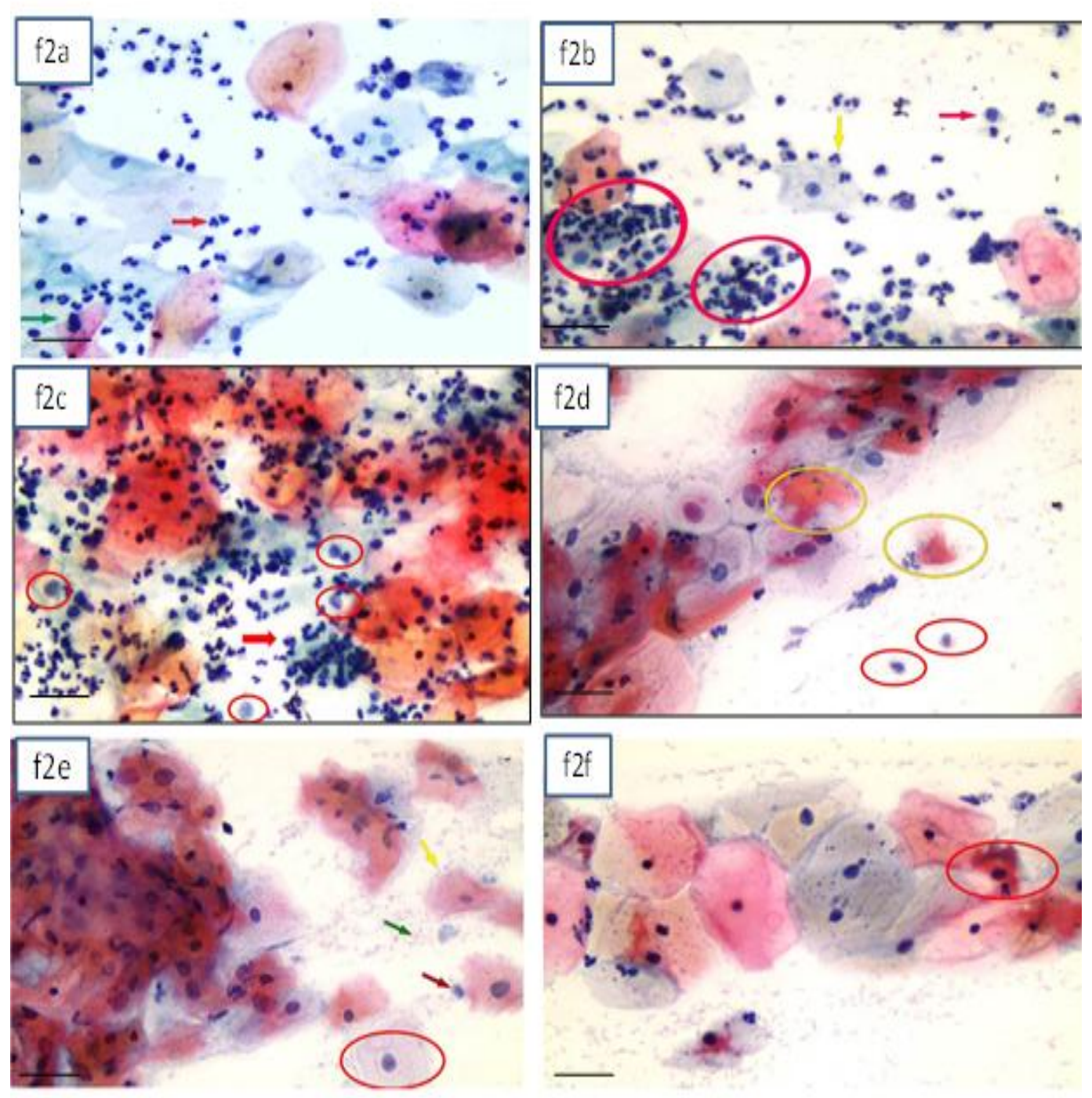

Fig.2 a, b, c, d, e \& $\mathbf{f}$ Cytopathological changes of vaginal smears by pap stain

Fig.2a Mild (+) acute inflammation in symptomatic infected subgroup showing few numbers of neutrophils (red arrow) with epithelial cells with reactive nuclear changes (green arrow) (x40) (scale bar $=30 \mu \mathrm{m})$. Fig.2b Moderate $(++)$ acute inflammation in symptomatic infected subgroup showed multiple cannon ball (red circles), collections of neutrophils (yellow arrow) on epithelial cells, T. vaginalis trophozoite (red arrow) and coccobacilli in background (x 40) (scale bar $=30 \mu \mathrm{m})$. Fig.2c Sever $(+++)$ acute inflammation in symptomatic infected subgroup showed multiple neutrophils masking epithelial cells with multiple cannon ball (red arrow) and $T$. vaginalis trophozoite (red circles) $(\mathrm{x} 40)$ (scale bar $=30 \mu \mathrm{m})$. Fig.2d T. vaginalis trophozoite (red circles) and ghost cell (yellow circles) in symptomatic infected females (x40) (scale bar $=30$ $\mu \mathrm{m})$. Fig.2e Perinuclear halo (red circle), T. vaginalis trophozoite (red arrow), coccobacilli (green arrow) and clue cell (yellow arrow) in symptomatic infected subgroup(x40) (scale bar = $30 \mu \mathrm{m})$. Fig.2f Squamous metaplasia in vaginal epithelial cells in symptomatic infected females $(\mathrm{x} 40)($ scale bar $=30 \mu \mathrm{m})$ 

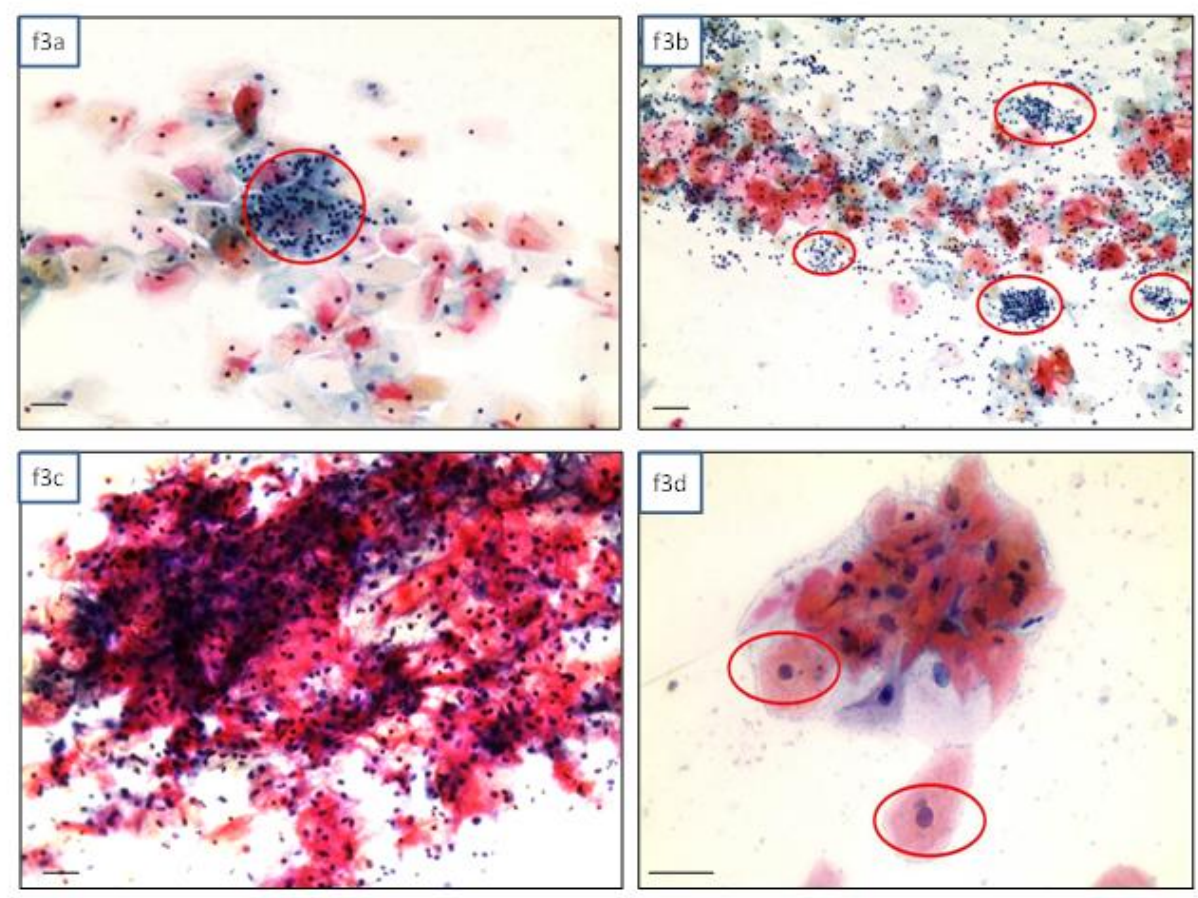

Fig.3 a, b, c \& d

Fig.3a Mild (+) chronic inflammation in asymptomatic infected subgroup showed cannon ball collection of lymphocytes on epithelial cells (red circles (x20). Fig.3b Moderate (++) chronic inflammation in asymptomatic infected subgroup showed multiple Cannon ball collections of lymphocytes (red circles) on epithelial cells (x10). Fig.3c Sever (+++) chronic inflammation in asymptomatic infected females (x20). Fig.3d Perinuclear halo (red circles) in asymptomatic infected subgroup $(x 40)$

This can be explained by important role of IL17 and IL-22 in the development of chronic inflammatory diseases (Valeri and Raffatellu, 2016). Also, the different immune evasion mechanisms by T.vaginalis and the elevated level of cytokines in asymptomatic infected females produce differences in symptoms of $T$ .vaginalis infection between infected females(Mercer and Johnson, 2018).

It was concluded that elevated cytokines (IL2, IL17, IL22) and INF $\gamma$ play a protective effect in asymptomatic $T$. vaginalis infected females proved by cytopathological inflammatory reaction and decrease symptoms in these females. It was recommended that the cytopathological changes in Pap smear is important in symptomatic T.vaginalis infected females to achieve early detection of nuclear changes, presence of halo cells and ghost cells that evaluate grades of inflammatory reactions.

\section{References}

Abou-kamar, W.A., Abdel-Mageid, A.A., ElNahas, H.A., Atia, R.A., Abou Elkhair, S.A., El-Tantawy, N.L., et al., 2017. Genetic Relatedness of Trichomonas vaginalis Isolates to the Clinical Variability. J. Mol. Microbiol. 1(1): 103.

Aboulghar, M.M., Abou-Shady, O.M., and Ahmed, J.A. 2009. Diagnosis of Trichomonas vaginalis Infection in Women of Childbearing Age at a University Setting Using OSOM A New Diagnostic Technique. Egyptian J. Med. 
Microbiol. 18(3): 51-56.

Albanesi, C., Scarponi, C., Cavani, A., Federici, M., Nasorri, F., and Girolomoni, G. 2000. Interleukin-17 is produced by both Th1 and Th2 lymphocytes, and modulates interferon-gamma- and interleukin-4induced activation of human keratinocytes. J. Invest. Dermatol.115: 81-87.

Alves, M.J., Oliveira, R., Balteiro, J., and Cruz, A. 2011. Epidemiologia de Trichomonas vaginalis em mulheres. Rev Port Saude Publica. 29: 27-34.

Baeten, J.M., Nyange, P.M., Richardson, B.A., Lavreys, L., Chohan, B., Martin, H.L.Jr., et al., 2001. Hormonal contraception and risk of sexually transmitted disease acquisition: Results from a prospective study. Am. J. Obstet. Gynecol. 185: 380385.

Barouti, E., Farzaneh, F., Sene, A. A., Tajik, Z., and Jafari, B. 2013. The pathogenic microorganisms in papanicolaou vaginal smears and correlation with inflammation. J. Family Reprod. Health. 7(1): 23-27.

Brabin, L. 2001. Hormonal markers of susceptibility to sexually transmitted infections: Are we taking them seriously? BMJ. 323: 394-395.

Caliendo, A.M., Jordan, J.A., Green, A.M., Ingersoll, J., Diclemente, R.J., and Wingood, G.M., 2005. Real-time PCR improves detection of Trichomonas vaginalis infection compared with culture using self collected vaginal swabs. Infect. Dis. Obstet. Gynecol. 13: 145-150.

Conti, H.R., Shen, F., Nayyar, N., Stocum, E., Sun, J.N., Lindemann, M.J., et al., 2009. Th17 cells and IL-17 receptor signaling are essential for mucosal host defense against oral candidiasis. J. Exp. Med. 206(2): 299-311.

Crucitti, T., Jespers, V., Mulenga, C., Khondowe, S., Vandepitte, J., and Buve, A. 2011. Non-sexual transmission of Trichomonas vaginalis in adolescent girls attending school in Ndola, Zambia. PloS One.6(1): e16310.

Depuydt, C.E., Leuridan, E., Van Damme, P., Bogers, J., Vereecken, A.J., and Donders, G.G. 2010. Epidemiology of Trichomonas vaginalis and human papillomavirus infection detected by real-time PCR in Flanders. Gynecol. Obstet. Invest. 70(4):273-80.

Dey, P. 2018. Cytology Sample Procurement, Fixation and Processing. In: Basic and Advanced Laboratory Techniques in Histopathology and Cytology. Springer, Singapore. 121-132.

Diamond, L.S., Clark, C.G., and Cunnick, C.C. 1995. YI-S, a casein-free medium for axenic cultivation of Entamoeba histolitica, related Entamoeba, Giardia intestinalis and T. vaginalis. J. Eukaryot. Microbiol. 42(3): 277-278.

Doshi, N.P. 2017. Comparison of Papanicolaou and Acridine Orange stains in the Diagnosis of Trichomonas vaginalis Infection in Vaginal Discharge. Annals Pathol. Lab. Med. 4(6): 750-751.

El-Gayar, E.K., Mokhtar, A.B., Awad, S.I., Soliman, R.H., and Hassan, W.A. 2016.The endosymbiotic relationship between Trichomonas vaginalis and Mycoplasma hominis in Egyptian Women and its correlation with pathogenicity. Parasitol. United J. 9: 80-86.

Elsherif, R.H., and Youssef, M.A. 2013. Realtime PCR improves detection of $T$. vaginalis compared to conventional techniques. Comp. Clin. Pathol. 22(2): 295-300.

Engvall, E., and Perlmann, P. 1971. Enzymelinked immunosorbent assay (ELISA). Quantitative assay of immunoglobulin G. Immunochemistry. 8:871-874.

Feng, J.Y., Rao, G.Z., Liu, Y.P., Li, P., Cui, R., Li, J.H., et al., 2009.Expression of CD1a and CD207 in condyloma acuminatum epidermis. Xi Bao Yu Fen Zi Mian Yi Xue Za Zhi. 25: 420-422.

Garcia, L.S., 2001. Diagnostic Medical Parasitology, 4th edit., ASM press, Washington, D.C:120-127.

Gavgani, A.S.M., Namazi, A., Ghazanchaei, A., Alizadeh, S., Sehhati, F., Rostamzadeh, S., et al., 2008. Prevalence and risk factors of trichomoniasis among women in Tabriz. Iran. J. Clinic. Infect. Dis. 3(2):6771.

Graves, K.J., Ghosh, A.P., Kissinger, P.J., and 
Muzny, C.A. 2019. Trichomonas vaginalis virus: a review of the literature. Int. J. STD. AIDS. 30(5): 496-504.

Hagag, H.M., Alam-Eldin, Y.H., Mahmoud, M.K., Ismail, K.A., Abdulaziz, A.M., Khalifa, A.M., et al., 2019. Perinuclear halo indicate Trichomonas vaginalis in Pap smear. Arch. Biotechnol. Biomed. 3: 001-005.

Hamad, M.N.M. 2018. Prevalence of Trichomonas vaginalis infection among reproductive age women admitted to soba university hospital, Sudan. Glob. J. Med. Res. 18: 2.

Hamdy, D.A., and Hamdy, H.G. 2018. Prevalence, sociodemographic factors and clinical criteria of Trichomonas vaginalis infection among symptomatic women in Beni-Suef Governorate, Egypt. J. Egypt. Soc. Parasitol. 48(1): 109 - 117.

Han, I.H., Goo, S.Y., Park, S.J., Hwang, S.J., Kim, Y.S., Yang, M.S., et al., 2009. Proinflammatory cytokine and nitric oxide production by human macrophages stimulated with Trichomonas vaginalis. Korean J. Parasitol. 47:205- 212.

Hobbs, M.M., and Sena, A.C. 2013. Modern diagnosis of Trichomonas vaginalis infection. Sex. Transm. Infect. 89: 434438.

Hollman, D., Coupey, S.M., Fox, A.S., and Herold, B.C. 2010. Screening for Trichomonas vaginalis in high-risk adolescent females with a new transcription-mediated nucleic acid amplification test (NAAT): associations with ethnicity, symptoms, and prior and current STIs. J. Pediatr. Adolesc. Gynecol. 23:312-6.

Hubacher, D. 2014. Intrauterine devices \& infection: review of the literature. Indian J. Med. Res. 140 (s1): S53-57.

Huppert, J.S. 2009. Trichomoniasis in teens: an update. Curr. Opin. Obstet. Gynecol. 21(5): 371-378.

Hussein, A.H., Saleh, M.H., Nagaty, I.M.A., Ghieth, K., and El-Azab, N.A. 2015. Prevalence, Clinical Criteria and Sociodemographic Predictors of Trichomonas vaginalis Infection in Suspected Egyptian Women, Using Direct
Diagnostic Techniques. Iran. J. Parasitol. 10(3): 432- 40.

Javanbakht, M., Stirland, A., Stahlman, Sh., Smith, L.V., Chien, M., Torres, R., et al., 2013. Prevalence and Factors Associated with Trichomonas vaginalis Infection among High-risk Women in Los Angeles. Sex. Transm. Dis. 40(10): 804-807.

Jha, R., Srivastava, P., Salhan, S., Finckh, A., Gabay, C., Mittal, A., et al., 2011. Spontaneous secretion of interleukin-17 and -22 by human cervical cells in Chlamydia trachomatis infection. Microbes Infect. 13(2): 167-78.

Lecke, S.B., Tasca, T., Souto, A.A., De Carli, G.A. 2003. Perspective of a new diagnostic for human trichomonosis. Mem Inst. Oswaldo. Cruz. 98: 273-276.

Lee, H.Y., Kim, J., Ryu, J.S., and Park, S.J. 2017.Trichomonas vaginalis $\alpha$-Actinin 2 Modulates Host Immune Responses by Inducing Tolerogenic Dendritic Cells via IL-10 Production from Regulatory $\mathrm{T}$ Cells. Korean J. Parasitol. 55(4): 375-384.

Lustig, G., Ryan, C.M., Secor, W.E., and Johnson, P.J. 2013.Trichomonas vaginalis contact dependent cytolysis of epithelial cells. Infect. Immun. 81(5): 1411-1419.

Madhivanan, P., Krupp, K., Hardin, J., Karat, C., Klausner, J.D., and Reinglod, A.L. 2009. Simple and inexpensive point-of-care tests improve diagnosis of vaginal infections in resource constrained settings. Trop. Med. Int. Health. 14: 703-708.

Mahmoud, A., Sherif, N.A., Abdella, R., ElGenedy, A.R., El Kateb, A.Y., and Askalani, A.N., 2015. Prevalence of Trichomonas vaginalis infection among Egyptian women using culture and Latex agglutination: cross-sectional study. BMC Womens Health. 15:7.

Makinde, H.M., Zariffard, R., Mirmonsef, P., Novak, R.M., Jarrett, O., Landay, A. L., et al., 2013. IL-22 levels are associated with Trichomonas vaginalis infection in the lower genital tract. Am. J. Reprod. Immunol. 70(1): 38-44.

Malla, N., Yadav, M., and Gupta, I. 2007. Kinetics of serum and local cytokine profile in experimental intravaginal trichomoniasis induced with Trichomonas 
vaginalis isolates from symptomatic and asymptomatic women. Parasitol. Immunol. 29(2):101-105.

Meites, E., Gaydos, C.A., Hobbs, M.M., Kissinger, P., Nyirjesy, P., Schwebke, J.R.,et al., 2015. A Review of Evidence-Based Care of Symptomatic Trichomoniasis and Asymptomatic Trichomonas vaginalis Infections. Clin. Infect. Dis.61(8): S837848.

Mercer, F.,and Johnson, P.J. 2018. Trichomonas vaginalis: Pathogenesis, symbiont Interactions, and host cell immune responses. Trends Parasitol. 34(8): 683693.

Nassef, N.A., Afif, A.F., Bauni, A.A., Abo ElNasr, M.F., and Atia, A.F. 2014. Evaluation of microscopy and polymerase chain reaction for diagnosis of symptomatic and asymptomatic female trichomoniasis. Parasitol. United J. 7(1): $37-46$.

Nicholls, J.E., Turner, K.M.E., North, P., Ferguson, R., May, M.T., Gough, K., et al., 2018. Cross-sectional study to evaluate Trichomonas vaginalis positivity in women tested for Neisseria gonorrhoeae and Chlamydia trachomatis, attending genitourinary medicine and primary care clinics in Bristol, South West England. Sex. Transm. Infect. 94(2): 9399.

Noël, J.C., and Engohan-Aloghe, C. 2010. Morphologic criteria associated with Trichomonas vaginalis in liquid-based cytology. Acta. Cytol. 54(4): 582-6.

Nograles, K.E., Zaba, L.C., Guttman-Yassky, E., Fuentes-Duculan, J., Suárez-Fariñas, M., Cardinale, I., et al., 2008. Th17 cytokines interleukin (IL)-17 and IL-22 modulate distinct inflammatory and keratinocyteresponse pathways. Br. J. Dermatol. 159(5): 1092-102.

Paintlia, M.K., Kaur, S., Gupta, I., Ganguly, N.K., Mahajan, R.C., and Malla, N. 2002. Specific $\operatorname{IgA}$ response, T-cell subtype and cytokine profile in experimental intravaginal trichomoniasis. Parasitol. Res. 88: 338-343.

Patil MJ, Nagamoti JM and Metgud SC (2012):
Diagnosis of Trichomonas vaginalis from vaginal specimens by wet mount microscopy, in pouch TV culture system and PCR. J. Global Infect. Dis., 4(1): 2225.

Petrin, D., Delgaty, K., Bhatt, R., and Garber, G. 1998. Clinical and microbiological aspects of Trichomonas vaginalis. Clin Microbiol Rev.11(2): 300-317.

Pickert, G., Neufert, C., Leppkes, M., Zheng, Y., Wittkopf, N., Warntjen, M., et al., 2009. STAT3 links IL-22 signaling in intestinal epithelial cells to mucosal wound healing. J. Exp. Med. 206(7):1465-1472.

Poole, D.N., and McClelland, R.S. 2013. Global epidemiology of Trichomonas vaginalis. Sex Transm. Infect. 89: 418-422.

Randonjic, I.V., Dzamic, A.M., Mitrovic, S.M., Arsenijevic, A.V., Popadic, D.M., and Kranjcic, Z.I. 2006. Diagnosis of Trichomonas vaginalis infection: the sensitivities and specificities of microscopy, culture and PCR assay. Eur.J. Obstet.Gynecol. Reprod. Biol. 126:116120.

Ranjit, E., Raghubanshi, B.R., Maskey, S., Parajuli, P. 2018. Prevalence of Bacterial Vaginosis and Its Association with Risk Factors among Nonpregnant Women: A Hospital Based Study. Int. J. Microbiol. 2018: 8349601.

Rowley, J., Hoorn, S.V., Korenromp, E., Low, N., Unemo, M., et al., 2019. Chlamydia, gonorrhoea, trichomoniasis and syphilis: global prevalence and incidence estimates, 2016. Bullworld Health Organ. 97:548562.

Ryan, C.M., de Miguel, N., and Johnson, P.J. 2011.Trichomonas vaginalis: current understanding of host parasite interactions. Essays Biochem. 51: 161-175.

Salih, M.M., AlHag, F.T.E.S., Khalifa, M.A., and El Nabi, A.H. 2017. Cervical cytopathological changes among women with vaginal discharge attending teaching hospital. J. Cytol. 34(2):90-94.

Schwebke, J.R. 2005. Trichomoniasis in adolescents: a marker for the lack of a public health response to the epidemic of sexually transmitted diseases in the United States. J. Infect. Dis., 192: 2036-2038. 
Schwebke, J.R., and Burgess, D. 2004. Trichomoniasis. Clin. Microbiol. Rev. 17(4): 794-803.

Shafir, S.C., Sorvillo, F.J., and Smith, L. 2009. Current Issues and Considerations Regarding Trichomoniasis and Human Immunodeficiency Virus in AfricanAmericans. Clin. Microbiol. Rev. 22 (1): 37-45.

Siracusano, S., Silvestri, T., and Casotto, D. 2014. Sexually transmitted diseases: epidemiological and clinical aspects in adults. Urologia. 81: 200-208.

Stute, P., Kollmann, Z., Bersinger, N., von Wolff, M., Thurman, A.R., and Archer, D.F. 2014. Vaginal cytokines do not differ between postmenopausal women with and without symptoms of vulvovaginal irritation. Menopause. 21(8):840-845.

Sutton, M., Sternberg, M., Koumans, E.H., McQuillan, G., Berman, S., and Markowitz, L. 2007. The prevalence of Trichomonas vaginalis infection among reproductive age women in the United States, 2001-2004. Clin. Infect. Dis.45(10): 1319-1326.

Tine, R.C., Sylla, K., Rougyatou, Ka., Lamine, Dia., Sow, D., Lelo, S., et al., 2019. A
Study of Trichomonas vaginalis Infection and Correlates in Women with Vaginal Discharge Referred at Fann Teaching Hospital in Senegal. J. Parasitol. Res. 2019: 1-8.

Ton, Nu. PA., Nguyen, V.Q., Cao, N.T., Dessi, D., Rappelli, P., and Fiori, P.L. 2015. Prevalence of Trichomonas vaginalis infection in symptomatic and asymptomatic women in Central Vietnam. J. Infect. Dev. Ctries. 9(6): 655-660.

Valadkhani, Z., Assmar, M.B., Esfandiari, B., Amirkhani, A., N. Hassan, N., Lotfi, M., et al., 2008.Trichomoniasis in Asymptomatic Patients. Iranian J. Publ. Health. 37(3): 113-117.

Valeri, M., and Raffatellu, M. 2016. Cytokines IL-17 and IL-22 in the host response to infection. Pathog. Dis. 74(9):ftw111.

Zaki, M.M., Moussa, H., and Hassanin, O.M. 2011. Evaluation of the OSOM Trichomonas Rapid Test for Detection of Trichomoniasis. PUJ. 4(2):177-184.

Zheng, Y., Valdez, P.A., Danilenko, D.M., Hu, Y., Sa, S.M., Gong, Q., et al., 2008. Interleukin-22 mediates early host defense against attaching and effacing bacterial pathogens. Nat. Med. 14(3): 282-289.

\section{How to cite this article:}

Asmaa R. Hegazy, Wafaa M. El Kersh, Ismail M. Moharm, Amany I. Ammar, Aiat S. Hemida and Amany F. Atia. 2020. Immunological and Cytopathological Assessment of Trichomonas vaginalis Infection in Asymptomatic and Symptomatic Females at Menoufia Governorate, Egypt. Int.J.Curr.Microbiol.App.Sci. 9(04): 686-705. doi: https://doi.org/10.20546/ijcmas.2020.904.083 